\title{
Commentary Human population structure, genome autozygosity and human health
}

\author{
Harry Campbell ${ }^{*}$, Igor Rudan*†, Alan H Bittles ${ }^{\ddagger}$ and Alan F Wright $§$
}

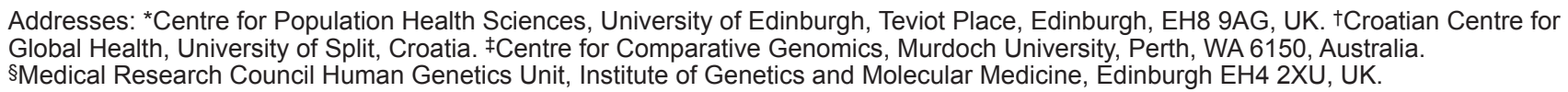

Correspondence: Professor Harry Campbell. Email: Harry.Campbell@ed.ac.uk

\begin{abstract}
A major transition in human population structure is currently under way, moving from a historical metapopulation, comprising small and mainly rural endogamous communities, to large and increasingly panmictic urban populations. This process is predicted to increase outbreeding, and preliminary data from genomic surveys have helped to quantify the potential magnitude of the effects. Population genetic trends of this nature should result in a reduced burden of recessive disorders, and have a favourable impact on complex diseases influenced by partially recessive genetic variants of smaller effect. The overall outcome is expected to be beneficial for a range of traits associated with human health and disease that show dominance variance.
\end{abstract}

\section{Introduction}

The demographic structure of human populations has changed dramatically over the last 200 years, resulting in major changes in the size and composition of gene pools. Prior to the 19th century, a large majority of the world's population lived and reproduced in small communities with restricted mate choice. During the last two centuries, the total human population has expanded from 1 to over 6.2 billion, and the percentage of the global population living in major towns and cities has increased from $2 \%$ to nearly $50 \%$ [1]. The migration of people from small, often isolated and genetically quite uniform communities to larger conurbations has led to a decline in endogamous and consanguineous marriage and to increased rates of marriage between partners from different geographical, ethnic, religious and social backgrounds [2,3]. Over the last 50 years, the process of 'isolate break-up' has led to the admixture of many genetically differentiated populations. This has increasingly involved intercontinental migration which, in conjunction with rapid urbanization, has further contributed to gene flow and resulted in more diverse breeding pools. Mutation has also increased genetic diversity through the generation of large numbers of new rare variants $[4,5]$. Collectively, the changes have led to a decrease in the level of population substructure and linkage disequilibrium (LD) in European populations $[6,7]$.

\section{Empirical evidence of changing genetic structure \\ Demographic data}

Consanguineous marriage continues to be popular in many parts of Asia and Africa [8], although in East Asia a marked general decline in consanguinity has occurred since the mid-2oth century. Elsewhere, the picture is mixed with, for example, a partial reduction in consanguinity in South India, but no apparent change in the approximately 50\% of marriages contracted between first cousins in Pakistan. In the Middle East, a decline in consanguinity is seen in some Arab countries but there has been an increase in others [2]. In Iran, marked inter-ethnic differences in the prevalence of consanguinity make any national trend difficult to determine [9]. Cousin marriage has recently become a much more important issue in Europe, with over 10 million migrants from regions with high levels of consanguinity (North Africa, the Middle East, Turkey, Central Asia, and South Asia) now resident across the continent. Equivalent information on the level of consanguinity among migrant communities in the USA is hampered by the fact that first cousin marriage is prohibited or a criminal offence in 31 of the 50 states [2].

\section{Genetic data}

A predicted effect of the admixture of individuals from different genetic populations is an increase in average individual genome-wide heterozygosity, $h$, as previously reported for morphometric and biochemical parameters among younger Israelis [10]. Using genomic data, Rudan and colleagues [11] measured $h$ in Croatian populations and demonstrated that levels are increasing through urbanization, isolate break-up and admixture. The observed wide range of variation in $h$ was unlikely to be stochastic since it was closely correlated with individual genetic histories, leading to the conclusion that population 
substructure, recent inbreeding and population admixture were the underlying mechanisms.

High-density single nucleotide polymorphism (SNP) analysis has been used to monitor the impact of these population changes on individual and community levels of autozygosity - defined as homozygosity in which each allele is derived from the same ancestral gene (that is, is identical by descent). Whole-genome SNP data have demonstrated short runs of homozygosity (ROH) measuring tens of kilobases (kb) and covering up to one-third of the autosomal genome, which are indicative of ancient LD patterns [12]. Longer $\mathrm{ROH}$ tracts (for example, $>500 \mathrm{~kb}$ ) provide a useful measure of more recent consanguinity. These regions can be used to infer the autozygosity status of genomic regions and, by summing the overall length of $\mathrm{ROH}$ regions above a minimum size, they provide a good summary measure of individual genome-wide homozygosity [12]. Long genomic segments containing $\mathrm{ROH}$, which reflect inheritance from a recent common ancestor, are common in many populations, including Han Chinese, indigenous Taiwanese, Caucasians and African Americans [13-19]. Increased urbanization and population admixture in the USA have been associated with a steady decrease in the size and frequency of $\mathrm{ROH}$ regions over the course of the 20th century: there has been an estimated $14 \%$ decrease in $\mathrm{ROH}$ frequency, a $24 \%$ decrease in the amount of the genome in $\mathrm{ROH}$, and a $30 \%$ reduction in the inbreeding coefficient, $F_{\mathrm{ID}}$ [20]. Since Europeans have the smallest among-population variance component, the trend of decreasing autozygosity with younger chronological age in the North American population of European ancestry studied by Nalls et al. [20] has important implications for the populations of other continents, where urbanization may exert even larger effects on genomic organization.

\section{Predicted health effects Impact on the prevalence of recessive single-gene disorders}

A reduction in autozygosity through outbreeding should decrease the burden of recessive monogenic disorders in communities with a high prevalence of consanguineous marriages [21-23]. A detailed prospective study of the Pakistani community in Birmingham, UK, indicated a significantly higher prevalence of autosomal recessive disorders among the progeny of consanguineous couples [24]. On the basis of these data, it has been calculated that there would be an approximate $7 / 1,000$ increase in autosomal recessive disorders per 0.01 increase in the mean coefficient of inbreeding [25]. If this estimate is applied to the reduction in inbreeding coefficient reported by Nalls et al. [20], then one could infer that approximately $1 \%$ of the annual births affected with an autosomal recessive disorder have been avoided in the North American population due to the 100-year population trends that have been identified.
Considered on a longer time scale, the reduced numbers of affected homozygotes will, however, result in decreased selection against the causative disease alleles and eventually result in their increased incidence in the gene pool. At the same time, due to isolate break-up, a higher proportion of affected individuals will be compound heterozygotes with different mutations inherited from each parent.

\section{Impact on the prevalence of complex diseases influenced by partially recessive genetic variants}

Outbreeding has long been known to influence complex as well as monogenic traits that are influenced by recessive or partially recessive variants [26]. How large is this effect likely to be? Recessivity is thought to be a property of multi-enzyme systems, which results in enzymatic safety margins, so that a reduction in the activity of a single allele will generally have little impact on the metabolic pathway [27]. The majority of genetic changes in enzymes, which make up 25 to $30 \%$ of gene products [28], are expected to show recessive or partially recessive phenotypes, whereas a smaller proportion is expected for non-enzymic proteins. Deleterious mutations are more likely to be recessive, while neutral or small-effect mutations are more often additive [26]. A wide variety of complex traits in many organisms are influenced by inbreeding, although it is unclear why the genetic (dominance) effects tend to be unidirectional. Most of the variants affecting human complex traits remain to be identified but a recent study suggested that partially recessive effects of relatively high penetrance may explain a proportion of the genetic predisposition to schizophrenia [16]. Therefore, just as the offspring of consanguineous matings may have lower mean health and fitness because of the homozygous expression of detrimental recessive alleles [29-32], similar effects could operate with the more numerous partially recessive variants influencing complex diseases.

\section{Impact on variation in quantitative traits underlying complex diseases}

In theory, any increase in individual genome-wide heterozygosity would be expected to influence variation in biological traits that show significant variance due to recessive alleles (dominance variance) [33,34], such as systolic blood pressure (BP), total cholesterol and lowdensity lipoprotein cholesterol $[35,36]$. Additionally, it has been proposed that these changes may have a significant impact in modifying the epigenetic, epistatic and polygenic pathways that influence complex traits [20].

Rudan and colleagues [29] found a positive linear relationship between the inbreeding coefficient and both systolic and diastolic BP in a Croatian population, with recessive or partially recessive genetic variants accounting for 10 to $15 \%$ of the total variation in BP. A decrease in mean inbreeding coefficient $\left(F_{\mathrm{ID}}\right)$ of 0.01 was associated with a reduction of approximately $3 \mathrm{mmHg}$ in systolic $\mathrm{BP}$ and $2 \mathrm{mmHg}$ in diastolic BP in both sexes [29]. Applying 
these findings to the change in mean inbreeding coefficient reported for the USA during the 20th century [20] would equate to an equivalent decrease of approximately $3 \mathrm{mmHg}$ in systolic BP and approximately $2 \mathrm{mmHg}$ in diastolic BP in both sexes.

The associations between systolic and diastolic blood pressure and coronary heart disease events and stroke have been described in a meta-analysis of 61 cohort (prospective observational) studies [37] and in the largest reported metaanalysis of randomized trials of blood pressure reduction [38]. The results indicated that cardiovascular mortality showed a constant proportional change in risk for a specified change in blood pressure (down to a diastolic BP of $70 \mathrm{mmHg}$ ). Regression coefficients were estimated from these data, facilitating the prediction of the proportional reduction in disease events for any age and blood pressure difference. The calculated regressions suggested that a decrease in adult diastolic and systolic BP of the magnitude derived from Rudan et al. [29] and Nalls et al. [20] would result in reductions in the incidence of coronary heart disease (and heart failure events) and stroke of approximately 5 to $10 \%$ and 10 to $15 \%$, respectively [38].

\section{Conclusions}

The preliminary data suggesting the beneficial effects of decreased consanguinity on complex diseases [29,32,39] require replication in other populations before their general significance can be properly assessed. However, as traits that show dominance variance were responsible for some $20 \%$ of the total burden of disease in industrialized countries in 2000 (that is, hypertension 11\%; hypercholesterolemia 8\%) [40], even small effects on the prevalence of the common traits and conditions would have important public health implications at community and population levels. Future studies could also profitably consider other traits that showed marked secular trends during the 20th century, such as IQ, which may also have been influenced by the population genetic trends that accompany isolate break-up [41]. It is improbable that the favorable secular trends in health and life expectancy in human populations worldwide during recent decades can solely be explained by socioeconomic factors and improved health care, yet to date the influence of marriage patterns on population genetic structure has been substantially underinvestigated. Until this issue is better understood, the potential role of outbreeding in the inheritance of polygenic traits and complex human diseases cannot readily be dismissed and merits further detailed study.

In purely practical terms, the predicted increase in the proportion of compound heterozygotes that will accompany outbreeding will make screening programs for recessive single-gene disorders and conditions involving partially recessive variants less predictable. However, the current rapid advances in whole-genome screening should solve this issue in a cost-effective manner.

\section{Competing interests}

The authors declare that they have no competing interests.

\section{Authors' contributions}

All authors contributed to the text of this commentary and reviewed the final version before publication.

\section{Acknowledgements}

AHB was supported by NSF grant number 0527751.

\section{References}

1. Clark D. Urban World, Global City. Oxford: Routledge; 2004.

2. Bittles $\mathrm{AH}$ : $\mathbf{A}$ community genetics perspective on consanguineous marriage. Commun Genet 2008, 11:324-330.

3. Darvasi A, Shifman S: The beauty of admixture. Nat Genet 2005, 37:118-119.

4. Wright A, Charlesworth B, Rudan I, Carothers A, Campbell H: A polygenic basis for late-onset disease. Trends Genet 2003, 19:97-106

5. Reich DE, Lander ES: On the allelic spectrum of human disease. Trends Genet 2001, 17:502-510.

6. Helgason A, Ingvadottir B, Hrafnkelsson B, Gulcher J, Stefansson K: An Icelandic example of the impact of population structure on association studies. Nat Genet 2005, 37: 90-95.

7. Vitart V, Carothers AD, Suffolk R, Hayward C, Teague P, Hastie ND, Campbell H, Wright AF: Increased level of linkage disequilibrium in rural compared to urban communities: a factor to consider in association study design. Am J Hum Genet 2005, 76:763-772.

8. Consanguinity/Endogamy Resource [http://www.consang net/index.php/Main_Page] (accessed 11 September 2009).

9. Abbasi-Shavazi MJ, McDonald P, Hosseini-Chavoshi M: Modernization or cultural maintenance: the practice of consanguineous marriage in Iran. J Biosoc Sci 2008, 40: 911-933

10. Kobyliansky E, Livshits G: Age-dependent changes in morphometric and biochemical traits. Ann Hum Biol 1989, 16: 237-247.

11. Rudan I, Carothers AD, Polasek O, Hayward C, Vitart V, Biloglav Z, Kolcic I, Zgaga L, Ivankovic D, Vorko-Jovic A, Wilson JF, Weber JL, Hastie N, Wright A, Campbell H: Quantifying the increase in average human heterozygosity due to urbanisation. Eur J Hum Genet 2008, 16:1097-1102.

12. McQuillan $\mathrm{R}$, Leutenegger $\mathrm{AL}$, Abdel-Rahman R, Franklin CS, Pericic M, Barac-Lauc L, Smolej-Narancic N, Janicijevic B, Polasek O, Tenesa A, Macleod AK, Farrington SM, Rudan $P$, Hayward C, Vitart V, Rudan I, Wild SH, Dunlop MG, Wright AF, Campbell $\mathrm{H}$, Wilson JF: Runs of homozygosity in European populations. Am J Hum Genet 2008, 83:359-372.

13. Broman $\mathrm{K}$, Weber J: Long homozygous chromosomal segments in reference families from the Centre d'Etude du Polymorphisme Humain. Am J Hum Genet 1999, 65:14931500.

14. Gibson J, Morton N, Collins A: Extended tracts of homozygosity in outbred human populations. Hum Mol Genet 2006, 5:789-795.

15. Li LH, Ho SF, Chen CH, Wei CY, Wong WC, Li LY, Hung SI, Chung WH, Pan WH, Lee MT, Tsai FJ, Chang CF, Wu JY, Chen YT: Long contiguous stretches of homozygosity in the human genome. Hum Mutat 2006, 27:1115-1121.

16. Lencz T, Lambert C, DeRosse P, Burdick KE, Morgan TV, Kane JM, Kucherlapati R, Malhotra AK: Runs of homozygosity reveal highly penetrant recessive loci in schizophrenia. Proc Natl Acad Sci U S A 2007, 104:19942-19947.

17. Simon-Sanchez J, Scholz S, Fung HC, Matarin M, Hernandez D, Gibbs JR, Britton A, Wavrant de Vrieze F, Peckham E, Gwinn- Hardy K, Crawley A, Keen JC, Nash J, Borgaonkar D, Hardy J, Singleton A: Genome-wide SNP assay reveals 
structural genomic variation, extended homozygosity and cell-line induced alterations in normal individuals. Hum Mol Genet 2007, 16:1-14.

18. Curtis D, Vine AE, Knight J: Study of regions of extended homozygosity provides a powerful method to explore haplotype structure of human populations. Ann Hum Genet 2008, 72:261-278.

19. Wang S, Haynes C, Barany F, Ott J: Genome-wide autozygosity mapping in human populations. Genet Epidemiol 2009, 33:172-180.

20. Nalls MA, Simon-Sanchez J, Gibbs JR, Paisan-Ruiz C, Bras JT, Tanaka T, Matarin M, Scholz S, Weitz C, Harris TB, Ferrucci L, Hardy J, Singleton AB: Measures of autozygosity in decline: globalization, urbanization, and its implications for medical genetics. PLoS Genet 2009, 5:e1000415.

21. Bittles $A H$, Mason WM, Greene J, Rao NA: Reproductive behaviour and health in consanguineous marriages. Science 1991, 252:789-794.

22. Bittles $A H$, Neel JV: The costs of human inbreeding and their implications for variations at the DNA level. Nat Genet 1994, 8:117-121.

23. Bittles $\mathrm{AH}$ : Consanguinity and its relevance to clinical genetics. Clin Genet 2001, 60:89-98.

24. Bundey $\mathrm{S}$, Alam $\mathrm{H}$ : A five-year prospective study of the health of children in different ethnic groups, with particular reference to the effect of inbreeding. Eur J Hum Genet 1993, 1:206-219.

25. Christianson A, Howson, CP, Modell B: March of Dimes Global Report on Birth Defects. White Plains, NY: March of Dimes Birth Defects Foundation; 2006.

26. Lynch M, Walsh B: Genetics and Analysis of Quantitative Traits. Sunderland: Sinauer Associates; 1998.

27. Bourguet D: The evolution of dominance. Heredity 1999, 83: $1-4$.

28. Jimenez-Sanchez G, Childs B, Valle D: Human disease genes. Nature 2000, 4009:853-855.

29. Rudan I, Campbell H, Carothers A, Wright A, Smolej-Narancic $\mathrm{N}$, Skaric-Juric T, Rudan P: Inbreeding and the genetic complexity of human hypertension. Genetics 2003, 163:10111021.

30. Rudan I, Rudan D, Campbell H, Carothers A, Wright A, Deka R, Smolej-Narancic N, Janicijevic B, Rudan P: Inbreeding and risk of complex chronic diseases. J Med Genet 2003, 40: 925-932.
31. Rudan I, Campbell H: Five reasons why inbreeding may have considerable effect on post-reproductive human health. Coll Antropol 2004; 28:943-950.

32. Rudan I, Campbell H, Carothers AD, Hastie ND, Wright AF: Contribution of consanguinity to polygenic and multifactorial diseases. Nat Genet 2006, 38:1224-1225.

33. Charlesworth B, Hughes KA: Age-specific inbreeding depression and components of genetic variance in relation to the evolution of senescence. Proc Natl Acad Sci U S A 1996, 93:6140-6145.

34. Falconer DS, Mackay TFC: Introduction to Quantitative Genetics. 4th edition. Harlow: Prentice Hall; 1996.

35. Ober C, Abney M, McPeek MS: The genetic dissection of complex traits in a founder population. Am J Hum Genet 2001, 69:1068-1079.

36. Abney M, McPeek MS, Ober C: Broad and narrow heritabilities of quantitative traits in a founder population. $A m ~ J$ Hum Genet 2001, 68:1302-1307.

37. Prospective Studies Collaboration: Age-specific relevance of usual blood pressure to vascular mortality: a meta-analysis of individual data for one million adults in 61 prospective studies. Lancet 2002, 360:1903-1913.

38. Law MR, Morris JK, Wald NJ: Use of blood pressure lowering drugs in the prevention of cardiovascular disease: meta-analysis of 147 randomised trials in the context of expectations from prospective epidemiological studies. BMJ 2009, 338:b1665.

39. Campbell H, Carothers AD, Rudan I, Hayward C, Biloglav Z, Barac L, Pericic M, Janicijevic B, Smolej-Narancic N, Polasek O, Kolcic I, Weber JL, Hastie ND, Rudan P, Wright AF: Effects of genome-wide heterozygosity on a range of biomedically relevant human quantitative traits. Hum Mol Genet 2007, 16: 233-241.

40. World Health Organization. World Health Report 2002: Reducing Risks, Promoting Healthy Life. Geneva: World Health Organization; 2002.

41. Mingroni MA: The secular rise in IQ: giving heterosis a closer look. Intelligence 2004, 32:65-83.

Published: 28 September 2009

doi:10.1186/gm91

(C) 2009 BioMed Central Ltd 